\title{
READERS' QUERIES
}

Professor Robert H. Woodward, 1535 Willowgate Drive, San Jose 24, California, would welcome information about the English career of the nineteenth century American novelist Harold Frederic. Best known for his novel The Damnation of Theron Ware, Frederic was in London from 1884 to 1898 as London correspondent of the New York Times. As a member of the Savage Club and the National Liberal Club, he must have come into contact with many journalists, authors, actors and political figures, and Professor Woodward is particularly anxious to know whether readers have come across any letters from or about him in manuscript collections in this country.

\section{GUIDE TO MANUSCRIPTS}

The Guide to Manuscripts Relating to America in Great Britain and Ireland, edited for the Association by B. R. Crick and Miriam Alman, (O.U.P., 84s.) has now been in print for almost a year. We hope to publish a review of it by Professor Merrill Jensen of the University of Wisconsin in our next issue. Meanwhile its publication has already prompted archivists and librarians to notify the editors of other material, and our next issue will also contain a list of these addenda as promised in the Introduction to the Guide.

\section{PUBLISHER'S ANNOUNCEMENT}

Oliver \& Boyd Ltd. have much pleasure in announcing that they are going to award a prize of $£ 500$ for the best original book in American Studies, especially Literature, Biography and History, submitted by any writer of British nationality. All books submitted as entries in this competition will be deemed to hove been offered to Oliver \& Boyd for publication under their imprint, and the closing date for submission of typescripts will be 30 September 1963. All who intend to compete are cordially invited to apply to the General Editorial Department, Oliver \& Boyd Ltd. , Tweeddale Court, 14, High Street, Edinburgh 1, for full details of the Conditions of Entry. 